\title{
クローン牛, 肉やミルクは安全か？
}

\section{前田照夫}

広島大学大学院生物圏科学研究科

クローン牛から生産された肉やミルクが市場に出回ってお り, 消費者がすでに口にしていることをご存知だろうか. ク ローン牛（C ビーフ）が食肉として出荷され始めるように なったのは 1993 年からであり, クローン牛のミルクが出荷 され始めたのは 1995 年からである. 厳密にはこれらの生産 物は, 受精卵クローン牛 (後述) 由来であり, 体細胞クロー ン牛由来ではない. 2008 年には, 厚生労働省と農林水産省 は, 体細胞クローン家畜由来食品の安全性を消費者に理解し てもらうために, 体細胞クローン家畜由来食品の安全性に関 する意見交換会（食品に関するリスクコミュニケーション） を東京と大阪で開催した，筆者はこの会に出席していないの で，どのような意見交換がなされたかは定かではないが，農 林水産省も厚生労働省も体細胞クローン家畜由来食品を市場 に出荷できるようにしたいようである，また，後述するが， 欧米でも日本と同様な動きがあり, 体細胞クローン牛の肉や ミルクが市場に出回る日も近いと考えられる.さて, 皆さん はクローン牛と表示された肉 (Cビーフ) やミルクをスー パーなどの店頭で目にしたら，積極的に買われるだろうか？ あるいは買うのを躊躇されるだろうか?

ここでは, クローン牛が生産された背景と目的, クローン 牛の作製方法とクローン牛の種類, 日本におけるクローン牛 の生産状況, 日本におけるクローン牛の取り扱いと受精卵ク ローン牛の表示および日本と海外に打けるクローン牛の食品 としての安全性と評価を紹介し, 消費者の皆さんが, 前述の 質問に対して，適切な判断ができるようになっていただくこ
とを期待する.

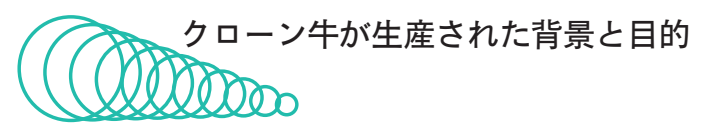

図 1 に示したように, クローン牛の生産に至った背景に は，我が国を含む世界中の研究者による家畜生産における生 殖技術の進歩があるといえる，本来の家畜生産の目標は，良 質な畜産物の安定供給であり, その目標を達成するために, 優良な家畜の精子や卵子を有効利用し，より生産効率を上げ るための技術開発が行なわれてきた.

まず，精子の人為的操作は，人工授精に始まり，1950 年以 降, 牛の人工授精技術の実用化, さらには 1960 年以降, 牛精 子の凍結保存屯実用化へと発展した。この実用化に伴い, 優 良な種オス牛の有効利用が可能となり, 肉やミルクの質と量 が飛躍的に改善された。ちなみに, 現在我が国で飼養されて いるほとんどの牛 $(99 \%$ 以上) は, 凍結保存した精液の人工 授精によって生産されている.

次に, 卵子の人為操作に関する技術では, 受精卵 (肧) 移 植が挙げられる.この技術開発は 1980 年代より開始され，こ の技術の普及により, 現在では優良なメス牛の子を多数生産 することも可能となり, クローン牛作出の基盤が整備され た。さらには牛卵子の体外成熟・受精・培養に関する技術開 発屯 1985 年以降急激に発展し, クローン牛の生産基盤が確 立した。

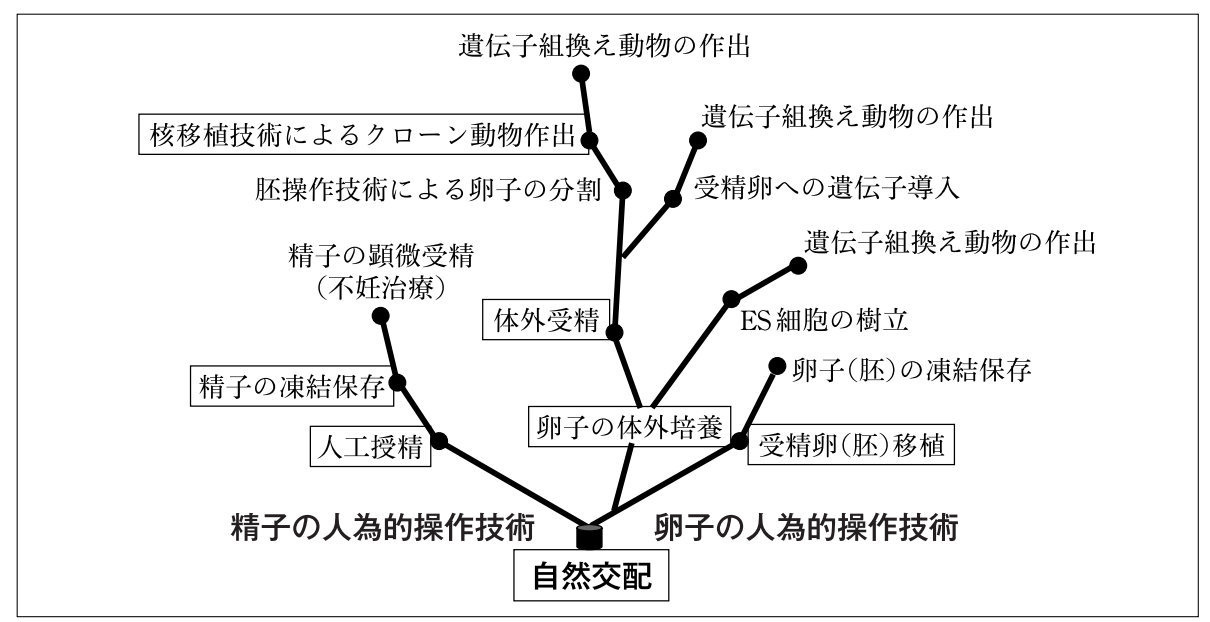

図 1 - 生殖工学技術の進展 


\section{表 1 ・クローン家畜の有用性}

家畜の改良・増殖
・肉用牛の育種改良（クローン検定）
・優秀な種オス牛の複製
・高泌乳牛の増産
試験用家畜の生産
・家畜の生理, 栄養, 管理などの試験・研究用家畜の生産
家畜を通した有用物質の生産（遺伝子組換え家畜を利用）
・乳汁に医薬品を分泌させる
・尿に生理活性物質を分泌させる
臟器移植用家畜生産（遺伝子組換え家畜を利用）
・遺伝子ノックアウト豚の開発

クローン牛の生産は, 前述のように優良な個体の多量生産 や効率的な生産を目的に，必然的に誕生したといえる．また， 今から約 10 年前, 世界中の研究者に衝撃を与えた, イギリス のロスリン研究所で誕生した体細胞クローン羊「ドリー」む クローン技術開発においてブレークスルーを起こした。つま り，1996 年までは, 我が国をはじめ世界中のクローン研究者 は，受精卵由来の胚細胞（未分化の細胞で，全能性を有する 細胞の核）を用いたクローン牛の効率的生産を目指してい た. しかし, クローン羊「ドリー」の誕生を契機として, 日 本でもいち早くドリーが生産されたのと同様の手法を用いた 体細胞クローン牛作出に関する研究が開始され, 1998 年に世 界初の体細胞クローン牛が日本で誕生した。

表 1 は, クローン家畜の有用性を示している。この技術は, 牛では肉用牛の育種改良, 優秀な種オス牛の複製, ミルクを たくさん生産する牛の増産などにすでに応用されており, 成 果を上げている。 また，この技術は，牛に限らず豚，緬羊， 山羊などの家畜においても応用され, 今後は試験や研究用 に，さらには遺伝子組換え技術によって作製された有用物質 を産出できる家畜や臟器移植用家畜の多量複製に応用される 可能性もある。したがって，この技術は，農学分野だけでな く医学や薬学の領域への貢献も大いに期待されている.

\section{核移植によるクローン牛の作製方法とク ローン牛の種類}

図 2 には，核移植によるクローン牛の作製方法の概要とク ローン牛の種類を示した。

クローン牛は，以下の手順（11)～(6)）で作製される.

(1)クローンを作出したい細胞（ドナー細胞）を用意する.

(2)未受精卵子から核を取り除いた（除核）除核卵子（レシ ピエント卵子）を用意する.

(3)ドナー細胞をレシピエント卵子の透明帯と卵細胞質の隙 間に挿入（核移植）する.

(4)細胞融合装置を用い，ドナー細胞とレシピエント卵子を 融合させる (細胞融合).

(5)約 1 週間，培養器内で培養する (体外培養).

(6)仮親の子宮に非外科的に移植し, 受胎した場合は, ク ローン牛が誕生することになる。

基本的な手順は，上記の通りであるが，用意するドナー細 胞の種類によって, クローン牛は, 受精卵クローン牛と体細 胞クローン牛の 2 つに区別される。まず，受精卵クローン牛 は，受精後数日間経過し，細胞分裂が進んだ受精卵（16〜32 細胞）をドナー細胞（未分化な細胞，全能性を有する細胞） として用いる．この受精卵を一つ一つの細胞（割球）に分け る. この操作が, 上記(1)の過程であり, (2)以降の過程を経て, クローン牛が作製される。この技術は，一卵性の双子や三つ 子のような複数子を生産する技術であり, たとえば 32 細胞 期の受精卵からドナー細胞が 32 個用意され，すべての過程 がうまくいけば，理論的には 32 頭のクローン牛が生産され ることになる。

一方, 体細胞クローン牛は, クローンを作出したい牛の皮 膚や筋肉などの体細胞（分化した細胞，全能性を有していな (細胞）を血清飢餓培養し, 細胞分裂を一時的にストップさ せ，ドナー細胞とする. その後は受精卵クローン牛の作出と 同様に，(2)以降の過程を経て，クローン牛を作製する。この 技術では，受精卵クローン牛のように，用意できるドナー細 胞数が限定されておらず，無数のクローン細胞をドナー細胞

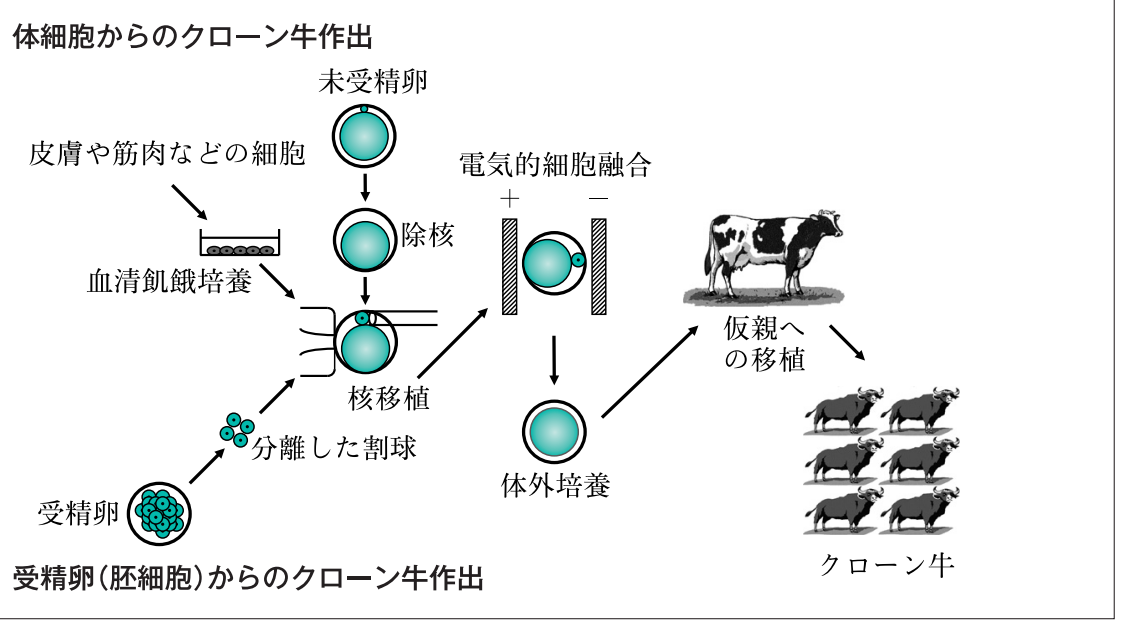

図 2 - 核移植によるクローン牛作 製法 
として用意できることから，理論的には無限の数のクローン 牛を作出できること, およびドナー細胞を提供した個体の遺 伝的能力がすでにわかっていること（優良な個体の複製）が 大きな利点である。なお, クローン牛の安全性については後 述するが，これまで記述したように，この技術はあくまでも 細胞を体外で処理しているだけであり, ドナー細胞核の遺伝 子組換えを行なっておらず，クローン牛は遺伝子組換え動物 でないことを理解していただきたい.

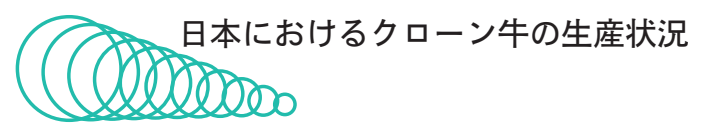

受精卵クローン牛は, 1990 年 8 月, 我が国で初めて誕生し て以来, 43 の試験・研究機関などで生産され, すでに 700 頭 以上 (2008 年 3 月 31 日現在, 716 頭) が誕生している. また, その内の 300 頭以上のクローン牛が食肉として出荷されてい る. 一方, 体細胞クローン牛については, 1998 年 7 月, 世界 初のクローン牛が我が国で誕生して以来, 42 の試験・研究機 関などで生産され，すでに 500 頭以上（2008 年 3 月 31 日現 在，515 頭）が誕生している。しかし，体細胞クローン牛は， 受精卵クローン牛とは異なり，一切市場には出荷されていな い（体細胞クローン家畜由来食品の安全性の項で詳述）。現 在, 受精卵クローン牛および体細胞クローン牛の生産頭数 は, 年々徐々に増加しているが，体細胞クローン牛について は, 食品としての安全性についてまだ最終的な評価が出てい ないことから, 試験・研究機関などで保有されている体細胞 クローン牛の肉もミルクもすべて廃棄されている状態であ る.したがって, 新たに体細胞クローン牛の生産や開発に取 り組む試験・研究機関数は, ここ数年激減しており, 体細胞 クローン牛生産に関する研究も 2000 年初期に比べ, 現在で はかなり衰退している感があるが，いずれにしても今後もク ローン牛の生産頭数は増加すると予想される.

\section{日本におけるクローン牛の取扱いと受精卵 クローン牛由来の生産物の表示}

クローン牛の取扱いに関して，農林水産省では，消費者な よ゙への説明会および学識経験者・消費者・研究者などによる 懇談会などでの意見も踏まえ, 表示を含め次のように取り扱 うことにしている.

(1)研究情報の公開を強化し, クローン牛の移動状況を 1 力 月ごとに公表する.

(2)受精卵クローン牛の出荷に際しては, 出荷基準に従って 受精卵クローン牛であることを明記した記録書を付して出荷 する.

(3)技術に対する正しい理解の促進のための普及啓発活動を 強化する。

(4)受精卵クローン牛由来生産物についての表示は任意とす る.
(5)受精卵クローン牛の通称については「受精卵クローン 牛」あるいは「Cビーフ」とする。

(6)体細胞クローン牛およびその生産物の出荷は, 現時点で は自肃する。

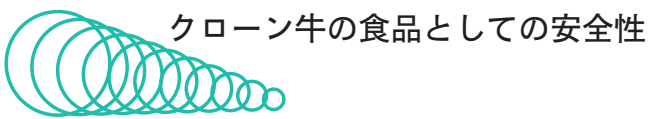

これまで記述したように，家畜クローン技術は，核移植な どの技術を用いて遺伝的に同一なクローン家畜を作製する技 術であり, 遺伝子の改変や操作を一切行なってはいない. 言 い換えれば，一卵性の双子や三つ子を人工的につくる技術で あり, 植物でいえば, 㨆や組織培養技術に相当する技術で ある.

図 3 には日本における牛肉の検査方法の概要を示してい る. 受精卵クローン牛肉については，一般の牛肉と同様に， 「之畜場法」と「食品衛生法」のもとに, 食肉衛生検查所にお いて，生体に異常がないか，内臓・肉などに異常がないかな ご厳密な検査が実施されている。これまでの受精卵クローン 牛肉に扔ける食品衛生上の病理学的・理化学的な検査結果で は，受精卵クローン牛肉と一般の牛肉との間には差がないこ とも確認されている. したがって, 結論的には受精卵クロー ン牛の食品としての安全性に問題があるとは考えられない.

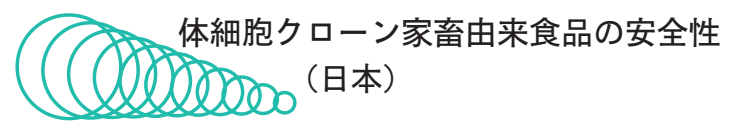

2008 年 4 月 1 日, 現厚生労働大臣である外添要一氏は, 「食品安全基本法」に基づき, 厚生労働省から食品安全委員会 に対して食品健康影響評価を依頼した。具体的な諮問事項 は，体細胞クローン技術を用いて産出された牛および豚なら びにそれらの後代*に由来する食品の安全性についてであ り，この委員会で体細胞クローン家畜由来食品に関する主な 知見の吟味之欧米での評価結果を参考に現在審議が行なわれ ている，また，冒頭にも述べたように，厚生労働省と農林水 産省は, 2008 年, 体細胞クローン家畜由来食品の安全性に関 する意見交換会（食品に関するリスクコミュニケーション） を東京と大阪で開催し, 消費者への理解を求めるよう努力し ている．さらに，体細胞クローン技術に関する日本の研究結 果 (平成 12 14(2000 2002) 年度厚生労働省科学研究費補助 事業）による結論では，体細胞クローン牛については，「従来 の技術により産出された牛にはない特有の要因によって食品 の安全性が損なわれるとは考え難い」と結論している．また， 最新の研究結果 (平成 16～20(2004～2008) 年度先端技術を活 用した農林水産研究高度化事業）においても以下のように結 論している.

*後世代のこと．つまりクローン技術を用いて生まれた動物が, 有性生殖 (オスの精子とメスの卵子とが受精すること) で繁殖し た結果，生まれた子棌たち 


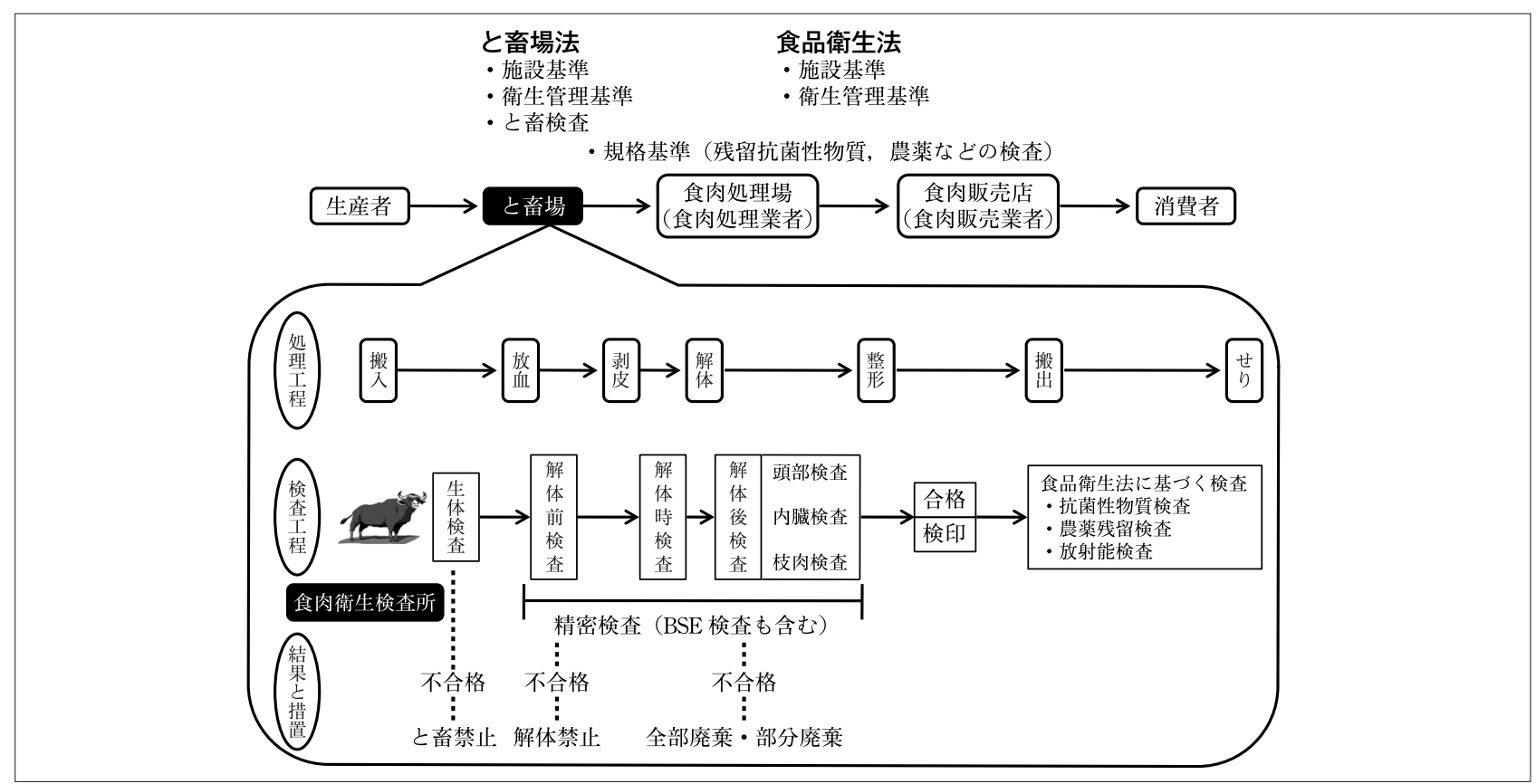

図 3 『牛肉（クローン牛肉も含む）の検査について 出典：厚生労働省資料より抜粋，一部改変

(1)体細胞クローン牛, 後代牛の臨床・病理（血液性状, 病 理など), 成長・発育, 繁殖性および乳肉生産のデー夕を分析 した結果，生後 200 日以上生存した体細胞クローン牛は，一 般牛と同程度に発育し, 一般牛之差異のない生理機能を有す ることが判明した。

(2)体細胞クローン後代牛においても, データが存在するい ずれの調査分野においても，一般牛之差異は認められなかっ た.

(3)体細胞クローン牛およびその後代牛が生産した乳肉の生 産性状調査において, 栄養成分分析, アレルギー誘発試験, 消化試験, 小核試験*, 飼養試験の各検査で得られたデー夕を 一般牛が生産した乳肉で得られたものと比較した結果, 生物 的な差異は認められなかった。

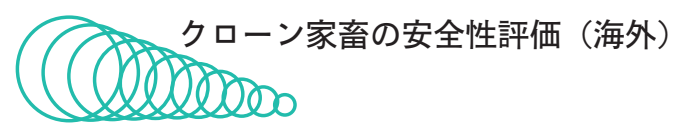

米国食品医薬品局は, FDA (Food and Drug Administration) と呼ばれ, 米国健康福祉省に設置された機関の一つで ある. FDA は, 医薬品, 食品, 医療機器, 化粧品などの効能 や安全性を確保することを通じて, 消費者の健康を守るため に必要な措置や調査研究を行なっている機関である，FDA は, 2008 年 1 月にクローン動物由来食品の安全性に関する報

*遺伝毒性やがん原性の有無を予測する試験のこと. つまり赤血 球あるいは細胞などを使い, 被験物質を投与したとき, それらの 細胞中における小核（遺伝子に生じた切断が修復されずそのま ま残るために生じたもの. 遺伝子損傷の残存量の指標となる）の 発生状況を調へ, 被験物質の安全性を判定する試験
告書を公表し, その報告書では, 牛, 豚および山羊のクロー ンおよびすべてのクローンの後代に由来する肉および乳は, 従来の方法で繁殖された動物に由来する食品と同様に食用と して安全であると結論付けた。同時に米国農務省 (USDA) は，牛，豚および山羊のクローンに由来する肉および乳に安 全性の懸念はなく, 上記 FDA の最終評価を全面的に支持し た. しかし，この安全宣言にもかかわらず，現実的には米乳 業最大手のディーン・フーズは,「クローン牛のミルクは受 け入れられない」と発表し, その理由として「米国民がク ローン牛の乳製品を買いたがっていないことは, 多くの調査 で明らかだ」と説明している，また，優良な体細胞クローン 牛を購入し, 新たな経営を試みた酪農家のパイオニア精神も 現実的には報いられていないのが米国の現状である.

欧州食品安全機関は, EFSA (Europe Food Safety Authority) と呼ばれ, 欧州委員会 (EC: European Commission) とは独立した機関として設置され，食品の安全性に関 して, 欧州委員会などに科学的な助言を行なう組織である. EFSA は, 2008 年 1 月に, 体細胞クローン家畜およびすべて のクローンの後代に由来する食品（肉および乳）の安全性に 関して意見書 (案) を公表し, パブリックコメントを募集し た．その意見書では，体細胞クローン技術を用いて産出され た牛および豚ならびに後代に由来する食品（肉および乳）と， 従来の繁殖方法で産出された家畜に由来する食品との間には 安全性に関していかなる差異も存在しないであろうと記述 し，現在はパブリックコメントを踏まえ最終案をとりまとめ 中である.

豪州・ニュージーランド食品基準機関 (FSANZ : Food Standards Australia New Zealand) む, 2008 年, 国内で飼 
養されているクローン動物の厳密な調查を実施し, 現時点で は, クローン動物の飼育は研究環境の範囲内に限られてお り，フードチェーンには流通していないことを確認してい る. また, FSANZ は, クローン動物に由来する食品に関して 国際的な動向に注視するとともに, 最終リスク評価の所見を 検討する予定であるとしている.

以上，諸外国における評価む日本と同様な評価であり，ク ローン動物由来の食品は, 安全であると結論されているが, 欧米でも日本でも，体細胞クローン技術を用いた家畜に対し て出荷自肃要請が行なわれているのが現状である.

おわりに（最終的な結論として，クローン 牛, 肉やミルクは安全か?）

本稿では, クローン牛が生産された背景と目的, クローン 牛の作製方法とクローン牛の種類, 日本に扔けるクローン牛 の生産状況，日本に打けるクローン牛の取扱いと受精卵ク ローン牛の表示, ならびに日本と海外におけるクローン牛の 食品としての安全性と評価を紹介した。家畜生産に関わる一 研究者として専門的な立場からコメントすると, 前述のよう に, クローン技術は, あくまでも細胞を体外で処理して生産 されたものであり，遺伝子の組換えをまったく行なっておら ず，体細胞クローン牛も含め日本で生産されたクローン牛の 食品としての安全性には問題はないと考える。したがって, 筆者は, 日本の公的機関, つまり農林水産省, 厚生労働省お よび食品安全委員会からクローン牛由来の生産物は安全であ るとの評価ができるだけ早く公示されることを期待してい る. また, クローン牛由来の生産物を買うか買わないかはあ くまでも消費者に選択できるよう, その生産物には明確な表 示を行なうべきであると考える. 最後に, 筆者は, スーパー マーケットなどでクローン牛由来の肉やミルクを見つけた ら，その価格がリーズナブルなものであれば，積極的に買い たいと考えている。
なお，本稿では遺伝子組換え技術により生産された牛の生 産物の安全性については言及していない. 近い将来遺伝子組 換え技術により生産された家畜の安全性についても当然大き な問題となってくるであろう。遺伝子組換え家畜の安全性に ついては，より詳細な検証が当然必要であると考える.

本稿の作成に際しては, 厚生労働省ホームページ (HP) の 「クローン技術を用いた食品について」(1),「クローン家畜由来 食品に関する $\mathrm{Q} \& \mathrm{~A}\rfloor^{(2)}$, 農林水産省 HP の「クローン牛につ いて知っていますか」(3), 「家畜クローン研究の現状について 」(4) および食品安全委員会 HP の「体細胞クローン動物の現 状について な(5) などを参考にした. 以下の文献には出典に関 する URL を記載しているので参考にしていただきたい.

追記：上記原稿を執筆後, 2009 年 1 月 20 日の朝日新聞に 「クローン牛・豚は安全」という記事が掲載された。 この記事 には，『体細胞クローンの牛と豚を食用にすることについて， 内閣府食品安全委員会の新開発食品専門調査会のワーキング グループ (座長＝早川堯夫 (たかお) ・近畿大薬学総合研究所 長）は 19 日，「一般の繁殖技術で生産した牛・豚と同じ安全 性を持つ」とする報告書をまとめることを確認した。食品安 全委員会は，この報告書を基に健康影響評価書を作り，年度 明けに厚生労働相に通知する見通しだ。クローン由来の食品 の流通を認めるかどうかは, 厚労省・農林水産省が最終判断 する.』之記載されている. 厚労省・農林水産省の最終判断が いつどのように行なわれるかは定かではないが，筆者は各省 における早急な対応とこの案件に関する進展を期待してい る.

1) http://www.mhlw.go.jp/topics/bukyoku/iyaku/ syoku-anzen/clone/

2) http://www.mhlw.go.jp/topics/bukyoku/iyaku/ syoku-anzen/qa/dl/080407-1.pdf

3) http://www.s.affrc.go.jp/docs/clone_pamph/clone.pdf

4) http://www.s.affrc.go.jp/docs/press/2007/071031_1. $\mathrm{htm}$

5) http://www.fsc.go.jp/emerg/clone_03.html

\section{プロフィル}

森口亮 (Ryo Moriguchi) <略歴> 2002 年東北大学農学部生物生産科学科卒 業/2004 年同大学大学院農学研究科資源 生物科学専攻博士課程前期 2 年修了 $/ 2007$ 年同博士課程修後期 3 年修了 (農博) /同 年九州大学大学院農学研究院植物資源科学 部門学術研究員, 現在にいたるく研究テー マと抱負 $>$ 植物特異的な $O$-結合型糖鎖修 飾抑制技術の開発<趣味 $>$ 公共交通機関を 駆使した旅行, 晚酌, メカの観賞

養王田正文（Masafumi Yohda） $<$ 略
歴 $>1982$ 年東京大学工学部化学工学科卒 業/ 1984 年同大学大学院工学系研究科化 学工学専攻修士課程修了 / 1987 年同博士 課程単位取得退学/1987 年旭硝子(株) 中 央研究所 $/ 1991$ 年理化学研究所化学工学 研究室研究員/1996 年同研究所生化学シ ステム研究室先任研究員 / 1998 年東京農 工大学工学部助教授 $/ 2003$ 年同大学大学 院教授, 現在にいたる. 1988 年工博 (東京 大学）<研究テーマと抱負 $>$ 分子シャペロ ンの構造と機能, 酵素の反応機構の解明, バイオレメディエーション, 遺伝子解析技
術の開発などく趣味 >テニス

米山 弘一（Koichi Yoneyama）＜略 歴 $>1976$ 年東京大学農学部農芸化学卒 業/1978 年同大学大学院農学系研究科農 芸化学専攻修士課程修了／同年宇都宮大学 農学部助手 / 1987 年同助教授 / 1992 年同 大学雑草科学研究センター助教授 / 1997 年同教授，現在にいたるく研究テーマと抱 負 $>$ 植物間相互作用の生物有機化学的解析 <趣味 $>$ 読書, 音楽全般, ゴルフ 